\title{
SPATIAL SPECIALISATION OF LIVESTOCK IN HUNGARY
}

\author{
LEVENTE KOMAREK
}

\author{
University of Szeged, Faculty of Agriculture \\ Institute of Economics and Rural Development \\ Andrássy út 15, H-6800 Hódmezővásárhely, Hungary \\ komarek@mgk.u-szeged.hu
}

\begin{abstract}
The territorial location issues of livestock in the European Union and also in our country got into the focus over the past few years. There are different animal structures in the regions of our country and different animal species became dominant. The location and the development of certain animal types are affected by a number of socio-economic factors (the history of breeding, ownership, labour and capital assets, etc.). In case of the spatially differentiated species-structure, variable profitability, human-resource, technical standards, different risk factors and market opportunities must be taken into consideration in different regions. The actuality of the research topic is enhanced by the fact that nowadays the spatial structure of animal production has become an important key issue. That is why more and more research is needed in Hungary, primarily research studying and analysing the structural changes and principals of animal production in order to ensure that each region would have a rational and efficient breed-structure. In addition, it is expected in modern market economies that the various regions should specialize in animal species, for which they have the most favourable breeding conditions. In order to follow the livestock changes (spatial and structural) in the last decade, it was important to consider the spatial specialization of different species over time.
\end{abstract}

Keywords: livestock (cattle, pig, sheep, hen species), spatial specialisation

\section{INTRODUCTION}

Animal production used to have a leading role in Hungarian agriculture for a long time, which had a close correlation with the structure and the standard of plant production. (KOMAREK, 2007, 2008c)

In the era of planned economy the importance of agriculture within the whole national economy decreased considerably compared to the situation before 1938 due to the intensive industrialisation. This decrease, however, occurred beside a dynamic development and growth. Spectacular results were achieved mainly from 1961, after the large scale reorganisation of agriculture. In the mid 1980s our agriculture in many aspects got into the forefront of the world despite the fact that we had a lot to do concerning yield, production costs, production structure, the speed of adapting to the markets and the harmonisation between the elements of the food industry verticum. The mid 1980s saw a dynamic development in spite of the unequal pace, then various tensions and imbalances got into the surface in the field of agriculture (BENKÖ-KISS ET AL., 2010; BODNÁR AND HORVÁTH, 2005; KOMAREK, 2003, 2004).

After the regime change profound changes took place in all sectors of animal production and there was an entirely new situation. Animal production has serious difficulties since then. The volume of production declined, the composition became more diverse and the structure of production sometimes became irrational, difficulties arose in selling etc. Profitability decreased in the field of animal production overall and certain activities became uneconomic. The low level of profitability resulted in unreasonable production decline and also led to a never experienced decrease in the number of our livestock (HORVÁTH, 2002; KOMAREK, 2008a, 2008b, 2011). 


\section{MATERIAL AND METHOD}

The statistical data of the Hungarian Central Statistical Office were used as a source. An index was formed from the data in order to facilitate the comparison of special distribution within the animal production sectors. The investigation involved the temporal and spatial data of cattle, pig, sheep and hen stocks in the period from 2003 to 2013.

In the past few years and even nowadays the transformation of Hungarian agriculture resulted in significant changes in the sector-specific and spatial structure of animal production. These changes require examinations in order to find out if a regional specialisation can be observed in the spatial organisation of livestock. To answer these assumptions, mathematical and statistical methods used in spatial research were applied.

A widespread method for the measurement of specialization is the so called spatial specialization index. This indicator shows the national share of each unit area concerning a specific product or production branch. That's called common specialization index.

General formula:

$$
S_{k \ddot{o} z}=\frac{x_{r}}{x_{t}} \times \frac{t}{r}
$$

where:

$\mathrm{S}_{\mathrm{köz}}=$ common specialization index

$\mathrm{x}_{\mathrm{r}}=$ unit area value

$\mathrm{x}_{\mathrm{t}}=$ national value

$\mathrm{t}=$ territory of the country

$r=$ territory of the unit area

The common specialization index shows the share of a unit area from the national production of a specific product or production branch. The higher the specialisation index is, the higher the level of specialisation will be.

\section{RESULTS}

When investigating the spatial specialisation of Hungarian livestock overall we can conclude from the calculated data that there were changes in the rate of the specialisation concerning certain types of animals. In some regions the rate of specialisation strengthened with regard to the given species and in others they lost their role and significance during the past decade.

In the past years the cattle stock of Hungary was changing. There were 739000 cattle in 2003 and this number was decreasing during the years until it reached its lowest point of 682000 in 2010.

From 2011 until today there was a dynamic increase in the cattle stock, and by 2013 the number of animals reached and even exceeded the 783000 value of 2003 . The considerable increase of the purchase price of cattle in recent years had a part in that. In addition to the number of the animal stock, another important factor is its spatial specialisation. In case of cattle Györ-Moson-Sopron and Hajdú-Bihar Counties represented the highest specialisation value in the base year (2003). Then Fejér, Békés and Tolna Counties followed. During the period up to 2013 Hajdú-Bihar and Györ-Moson-Sopron Counties retained their prominent position in the field, however, while the rate of 
specialisation in Győr-Moson-Sopron County deceased, it was growing in Hajdú-Bihar County. Similarly, the rate of specialisation was growing in Békés County in the period between 2003 and 2013. In contrast, Fejér and Tolna Counties lost their importance in the field of cattle production.

Table 1. Spatial specialisation of cattle stock in Hungary

\begin{tabular}{|c|c|c|c|c|c|c|c|c|c|c|c|}
\hline Spatial Unit & 2003 & 2004 & 2005 & 2006 & 2007 & 2008 & 2009 & 2010 & 2011 & 2012 & 2013 \\
\hline Budapest & 0.63 & 0.65 & 0.58 & 0.58 & 0.83 & 0.42 & 0.42 & 0.37 & 0.36 & 0.49 & 0.40 \\
\hline Pest & 0.97 & 1.08 & 1.10 & 1.20 & 1.18 & 1.14 & 1.18 & 1.30 & 1.20 & 1.16 & 1.27 \\
\hline Central Hungary & 0.91 & 1.00 & 0.99 & 1.05 & 1.10 & 0.98 & 1.02 & 1.12 & 1.03 & 1.03 & 1.09 \\
\hline Fejér & 1.46 & 1.38 & 1.33 & 1.26 & 1.17 & 1.23 & 1.20 & 1.19 & 1.17 & 1.13 & 1.15 \\
\hline Komárom-Esztergom & 0.86 & 0.88 & 0.82 & 0.83 & 0.71 & 0.71 & 0.71 & 0.64 & 0.70 & 0.64 & 0.62 \\
\hline Veszprém & 1.12 & 1.11 & 0.98 & 1.02 & 1.14 & 1.09 & 0.99 & 0.99 & 1.08 & 1.05 & 1.10 \\
\hline $\begin{array}{l}\text { Central } \\
\text { Transdanubia }\end{array}$ & 1.23 & 1.18 & 1.10 & 1.08 & 1.08 & 1.08 & 1.02 & 1.00 & 1.04 & 1.01 & 1.02 \\
\hline Győr-Moson-Sopron & 1.75 & 1.91 & 1.74 & 1.75 & 1.80 & 1.82 & 1.76 & 1.63 & 1.68 & 1.68 & 1.52 \\
\hline Vas & 1.15 & 0.98 & 0.97 & 1.06 & 1.06 & 1.10 & 1.11 & 1.12 & 1.03 & 1.13 & 1.02 \\
\hline Zala & 0.68 & 0.75 & 0.84 & 0.95 & 0.84 & 0.81 & 0.74 & 0.82 & 0.73 & 0.74 & 0.75 \\
\hline West Transdanubia & 1.19 & 1.21 & 1.22 & 1.29 & 1.27 & 1.28 & 1.23 & 1.20 & 1.19 & 1.21 & 1.12 \\
\hline Baranya & 0.94 & 0.87 & 0.87 & 0.84 & 0.81 & 0.79 & 0.79 & 0.84 & 0.82 & 0.75 & 0.81 \\
\hline Somogy & 0.64 & 0.70 & 0.72 & 0.66 & 0.70 & 0.66 & 0.56 & 0.57 & 0.63 & 0.62 & 0.56 \\
\hline Tolna & 1.21 & 1.05 & 1.04 & 1.01 & 0.96 & 0.93 & 0.97 & 0.84 & 0.90 & 0.82 & 0.83 \\
\hline South Transdanubia & 0.89 & 0.85 & 0.85 & 0.81 & 0.80 & 0.77 & 0.74 & 0.72 & 0.76 & 0.72 & 0.71 \\
\hline $\begin{array}{l}\text { Borsod-Abaúj- } \\
\text { Zemplén }\end{array}$ & 0.67 & 0.70 & 0.77 & 0.74 & 0.69 & 0.77 & 0.78 & 0.76 & 0.71 & 0.68 & 0.79 \\
\hline Heves & 0.36 & 0.37 & 0.38 & 0.38 & 0.38 & 0.38 & 0.42 & 0.32 & 0.38 & 0.35 & 0.34 \\
\hline Nógrád & 0.54 & 0.66 & 0.67 & 0.63 & 0.68 & 0.79 & 0.79 & 0.64 & 0.63 & 0.58 & 0.66 \\
\hline North Hungary & 0.56 & 0.60 & 0.63 & 0.60 & 0.61 & 0.66 & 0.68 & 0.61 & 0.60 & 0.58 & 0.63 \\
\hline Hajdú-Bihar & 1.70 & 1.73 & 1.83 & 1.78 & 1.82 & 1.80 & 1.96 & 1.87 & 1.87 & 1.81 & 1.83 \\
\hline Jász-Nagykun-Szolnok & 1.09 & 1.10 & 1.15 & 1.07 & 1.04 & 1.07 & 1.02 & 1.02 & 1.09 & 1.10 & 1.15 \\
\hline $\begin{array}{l}\text { Szabolcs-Szatmár- } \\
\text { Bereg }\end{array}$ & 0.77 & 0.76 & 0.69 & 0.76 & 0.76 & 0.78 & 0.76 & 0.74 & 0.66 & 0.71 & 0.71 \\
\hline North Great Plain & 1.18 & 1.19 & 1.21 & 1.20 & 1.19 & 1.20 & 1.24 & 1.20 & 1.20 & 1.20 & 1.23 \\
\hline Bács-Kiskun & 0.82 & 0.76 & 0.73 & 0.78 & 0.82 & 0.83 & 0.84 & 0.89 & 0.95 & 1.02 & 0.93 \\
\hline Békés & 1.26 & 1.24 & 1.19 & 1.20 & 1.20 & 1.20 & 1.28 & 1.56 & 1.42 & 1.47 & 1.58 \\
\hline Csongrád & 1.08 & 1.08 & 1.25 & 1.11 & 1.04 & 1.08 & 1.08 & 1.03 & 1.10 & 1.09 & 0.95 \\
\hline South Great Plain & 1.01 & 0.97 & 0.98 & 0.98 & 0.99 & 1.00 & 1.02 & 1.12 & 1.12 & 1.17 & 1.13 \\
\hline
\end{tabular}

Source: Author's calculations based on KSH data

There were negative changes in the pig stock during the observation period. The number of pigs in 2003 was 4913 thousand, which fell back to 3013 within a decade meaning a $38.7 \%$ decrease from the base year to the reference year. Despite the fallback in pig numbers there are regions specialised on pig production. In the base year (2003) particularly Komárom-Esztergom, Hajdú-Bihar, Csongrád and Békés Counties were specialised in pig production. By the reference year (2013) the specialisation of the above counties in pig production decreased except Hajdú-Bihar County. In case of Hajdú-Bihar County there was even an intensive specialisation compared to the base year. In addition, 
Review on Agriculture and Rural Development 2014. vol. 3 (2) ISSN 2063-4803

in case of Baranya County we can observe growth in this field although it used to have lower specialisation previously.

Table 2. Spatial specialisation of pig stock in Hungary

\begin{tabular}{|c|c|c|c|c|c|c|c|c|c|c|c|}
\hline Spatial Unit & 2003 & 2004 & 2005 & 2006 & 2007 & 2008 & 2009 & 2010 & 2011 & 2012 & 2013 \\
\hline Budapest & 0.11 & 0.15 & 0.18 & 0.13 & 0.18 & 0.36 & 0.16 & 0.32 & 0.19 & 0.33 & 0.29 \\
\hline Pest & 0.67 & 0.64 & 0.71 & 0.70 & 0.73 & 0.73 & 0.74 & 0.73 & 0.63 & 0.43 & 0.48 \\
\hline Central Hungary & 0.57 & 0.55 & 0.59 & 0.57 & 0.61 & 0.65 & 0.61 & 0.65 & 0.54 & 0.41 & 0.44 \\
\hline Fejér & 0.90 & 0.77 & 0.79 & 0.65 & 0.56 & 0.54 & 0.46 & 0.52 & 0.60 & 0.62 & 0.58 \\
\hline Komárom-Esztergom & 2.09 & 1.73 & 1.82 & 1.63 & 1.61 & 1.97 & 1.78 & 1.92 & 1.39 & 1.28 & 1.34 \\
\hline Veszprém & 0.87 & 0.90 & 0.80 & 0.83 & 0.78 & 0.83 & 0.83 & 0.81 & 0.71 & 0.77 & 0.58 \\
\hline $\begin{array}{l}\text { Central } \\
\text { Transdanubia }\end{array}$ & 1.14 & 1.02 & 1.00 & 0.92 & 0.86 & 0.94 & 0.86 & 0.92 & 0.81 & 0.81 & 0.73 \\
\hline Győr-Moson-Sopron & 1.00 & 1.30 & 1.11 & 1.04 & 1.04 & 1.01 & 1.09 & 1.11 & 1.30 & 1.47 & 1.38 \\
\hline Vas & 0.43 & 0.48 & 0.46 & 0.46 & 0.36 & 0.39 & 0.34 & 0.31 & 0.33 & 0.33 & 0.31 \\
\hline Zala & 0.46 & 0.49 & 0.57 & 0.44 & 0.39 & 0.43 & 0.44 & 0.47 & 0.47 & 0.51 & 0.40 \\
\hline West Tra & 0.64 & 0.77 & 0.74 & 0.67 & 0.62 & 0.63 & 0.66 & 0.66 & 0.74 & $\mathbf{0 . 8 2}$ & 0.75 \\
\hline Baranya & 1.53 & 1.77 & 1.95 & 1.76 & 2.07 & 1.54 & 1.76 & 1.76 & 1.85 & 1.90 & 1.99 \\
\hline Somogy & 0.66 & 0.67 & 0.71 & 0.71 & 0.71 & 0.80 & 0.59 & 0.67 & 0.65 & 0.66 & 0.72 \\
\hline Tolna & 1.52 & 1.47 & 1.40 & 1.40 & 1.20 & 1.43 & 1.23 & 1.23 & 1.34 & 1.40 & 1.25 \\
\hline South Transdanubia & 1.16 & 1.23 & 1.29 & 1.23 & 1.28 & 1.20 & 1.14 & 1.16 & 1.21 & 1.25 & 1.27 \\
\hline $\begin{array}{l}\text { Borsod-Abaúj- } \\
\text { Zemplén }\end{array}$ & 0.44 & 0.35 & 0.38 & 0.35 & 0.39 & 0.39 & 0.42 & 0.37 & 0.39 & 0.40 & 0.41 \\
\hline Heves & 0.39 & 0.36 & 0.36 & 0.32 & 0.37 & 0.37 & 0.47 & 0.34 & 0.30 & 0.30 & 0.33 \\
\hline Nógrád & 0.36 & 0.30 & 0.35 & 0.30 & 0.31 & 0.26 & 0.29 & 0.25 & 0.29 & 0.11 & 0.11 \\
\hline North Hungary & 0.41 & 0.34 & 0.37 & 0.33 & $\mathbf{0 . 3 7}$ & 0.36 & 0.41 & 0.34 & 0.34 & 0.31 & $\mathbf{0 . 3 3}$ \\
\hline Hajdú-Bihar & 1.81 & 1.75 & 1.80 & 1.94 & 2.03 & 2.21 & 2.39 & 2.25 & 2.61 & 2.60 & 2.53 \\
\hline Jász-Nagykun-Szolnok & 0.99 & 0.92 & 1.05 & 1.02 & 1.04 & 1.07 & 1.07 & 1.00 & 1.06 & 1.14 & 1.19 \\
\hline $\begin{array}{l}\text { Szabolcs-Szatmár- } \\
\text { Bereg }\end{array}$ & 0.94 & 0.93 & 0.85 & 0.87 & 0.89 & 0.77 & 0.78 & 0.93 & 0.62 & 0.64 & 0.75 \\
\hline North Great Plain & 1.24 & 1.20 & 1.22 & 1.27 & 1.31 & 1.34 & 1.40 & 1.39 & 1.42 & 1.45 & 1.49 \\
\hline Bács-Kiskun & 1.07 & 1.04 & 1.10 & 1.12 & 1.26 & 1.14 & 1.09 & 1.17 & 1.12 & 1.13 & 1.21 \\
\hline Békés & 1.65 & 1.48 & 1.54 & 1.66 & 1.61 & 1.54 & 1.60 & 1.82 & 1.76 & 1.56 & 1.59 \\
\hline Csongrád & 1.69 & 2.09 & 1.55 & 1.91 & 1.47 & 1.61 & 1.63 & 1.18 & 1.34 & 1.40 & 1.27 \\
\hline South Great Plain & 1.39 & 1.42 & 1.34 & 1.47 & 1.41 & 1.37 & 1.37 & 1.36 & 1.36 & 1.32 & 1.34 \\
\hline
\end{tabular}

Source: Author's calculations based on KSH data

The Hungarian sheep stock mostly stagnated or somewhat decreased in the examination period. In 2003 the number of the animals reached 1296 thousand, which fell down to 1271 thousand by 2013. The stock peaked in 2005 (1405 thousand), while in 2011 the lowest ever number was observed (1120 thousand). Compared to the previous years, there were no significant changes regarding spatial specialisation. In the base year (2003) HajdúBihar, Szabolcs-Szatmár-Bereg and Bács-Kiskun Counties were specialised in sheep production the most intensely. Out of these three counties the specialisation of Hajdú-Bihar and Bács-Kiskun Counties increased by the reference year (2013) while in case of Szabolcs-Szatmár-Bereg County we could witness a decreasing specialisation. However, this county is still in the national forefront concerning sheep production in Hungary. 
The examinations prove that there have been no considerable spatial changes in sheep production recently.

Table 3. Spatial specialisation of sheep stock in Hungary

\begin{tabular}{|c|c|c|c|c|c|c|c|c|c|c|c|}
\hline Spa & 2003 & 2004 & 2005 & 2006 & 2007 & 2008 & 2009 & 2010 & 2011 & 2012 & 2013 \\
\hline Budapest & 0.62 & 1.10 & 0.67 & 0.68 & 0.71 & 0.80 & 0.72 & 0.80 & 0.34 & .84 & 0.78 \\
\hline Pest & 0.71 & .14 & 1.29 & 0.80 & 0.75 & 0.54 & .53 & 0.82 & 0.66 & 0.72 & 0.76 \\
\hline Centr & 0.69 & 1.12 & 1.16 & 0.77 & 0.73 & 0.60 & 0.57 & 0.81 & 0.60 & 0.74 & 0.76 \\
\hline Fejér & 0.83 & 0.72 & 0.70 & 0.82 & 0.80 & 0.68 & 0.62 & 0.56 & 0.58 & 0.55 & 0.56 \\
\hline Komár & 0.72 & 0.61 & 0.56 & 0.58 & 0.57 & 0.44 & 0.41 & 0.27 & 0.36 & 0.44 & 0.41 \\
\hline Veszprém & 0.99 & 03 & 0.91 & 0.95 & 0.76 & 0.63 & .59 & 0.94 & 1.34 & 0.85 & 0.88 \\
\hline $\begin{array}{l}\text { Central } \\
\text { Transdanubia }\end{array}$ & 0.86 & 0.81 & 0.75 & 0.82 & 0.73 & 0.61 & 0.57 & 0.65 & 0.83 & 0.65 & 0.65 \\
\hline Györ-Moson-So & 0.14 & 0.11 & 0.11 & 0.12 & 0.12 & 0.14 & 0.13 & 0.15 & 0.16 & 0.17 & 0.12 \\
\hline Vas & 0.09 & 0.20 & 0.12 & 0.09 & 0.09 & 0.07 & 0.07 & 0.10 & 0.10 & 0.10 & 0.09 \\
\hline Zala & 0.22 & 0.11 & 0.14 & 0.29 & 0.38 & 0.32 & 0.22 & 0.34 & 0.32 & 0.26 & 0.30 \\
\hline West Tra & 0.15 & 0.13 & 0.14 & 0.17 & 0.19 & 0.18 & 0.14 & 0.20 & 0.19 & 0.18 & 0.16 \\
\hline & 0 & 0.39 & 0.41 & & 0.46 & 0.48 & 77 & 0.48 & 0.38 & 8 & 0.43 \\
\hline Somogy & 0.27 & 0.32 & 0.30 & 0.28 & 0.28 & 0.25 & 0.27 & 0.37 & 0.38 & 0.34 & 0.40 \\
\hline Tolna & 1.21 & 1.24 & 1.37 & 1.30 & 1.21 & 0.90 & 0.84 & 0.90 & 0.85 & 0.92 & 1.01 \\
\hline South & 0.57 & 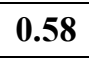 & $\mathbf{0}$ & 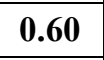 & 0 & 0.49 & 0.48 & 0.55 & 50 & 49 & .56 \\
\hline $\begin{array}{l}\text { Borsod- } \\
\text { Zemplén }\end{array}$ & 0.72 & 0.61 & 0.62 & 0.63 & 0.63 & 0.73 & 0.64 & 0.65 & 0.76 & 0.78 & 0.48 \\
\hline Heves & 0.47 & 0.49 & 0.52 & 0.43 & 0.36 & 0.38 & 0.58 & 0.33 & 0.46 & 0.39 & 0.50 \\
\hline Nógrád & 0.42 & 0.2 & 0.37 & 0.45 & 0.42 & 0.42 & 0.51 & 0.50 & 0.33 & 0.47 & 0.41 \\
\hline North $\mathrm{H}$ & 0.59 & 0.51 & 0.54 & 0.54 & 0.51 & 0.57 & 0.59 & 0.53 & 0.59 & 0.60 & 0.48 \\
\hline Hajdú-Bihar & 2.78 & 2.97 & 3.11 & 3.15 & 3.31 & 3.34 & 3.28 & 2.93 & 2.56 & 2.90 & 3.03 \\
\hline $\begin{array}{l}\text { Jász-Nagykun- } \\
\text { Szolnok }\end{array}$ & 0.73 & 0.76 & 0.87 & 0.72 & 0.73 & 0.69 & 0.84 & 0.95 & 1.03 & 1.04 & 1.18 \\
\hline $\begin{array}{l}\text { Szabolcs-Szatmár- } \\
\text { Bereg }\end{array}$ & 2.67 & 2.05 & 1.83 & 2.58 & 2.73 & 2.36 & 2.36 & 2.07 & 2.12 & 2.06 & 1.95 \\
\hline North Great Plain & 2.07 & 1.93 & 1.93 & 2.16 & 2.27 & 2.13 & 2.17 & 1.98 & 1.91 & 2.01 & 2.06 \\
\hline Bács-Kiskun & 1.81 & 2.10 & 1.84 & 1.73 & 1.58 & 2.06 & 2.00 & 1.80 & 1.93 & 1.79 & 1.84 \\
\hline Békés & 0.82 & 0.47 & 0.67 & 0.56 & 0.68 & 0.86 & 0.96 & 1.30 & 1.23 & 1.24 & 1.18 \\
\hline Csongrád & 0.88 & 1.02 & 1.05 & 0.87 & 0.95 & 0.99 & 1.06 & 1.05 & 1.11 & 1.19 & 1.06 \\
\hline South Great Plain & 1.30 & 1.36 & 1.31 & 1.18 & 1.17 & 1.45 & 1.47 & 1.47 & 1.52 & 1.48 & 1.45 \\
\hline
\end{tabular}

Source: Author's calculations based on KSH data

The stock of hen species showed a somewhat hectic pattern in the past ten years. There were both ups and downs characterizing the changes of this period. In 2003 there were 37502 thousand hens in the stock, which decreased to 29474 thousand by 2013 , meaning the lowest number of birds in the examination decade. In the base year (2003) the highest specialisation in case of hens was represented by Komárom-Esztergom County. Nationally, it was the county with the highest degree of specialization for breeding hens. Hajdú-Bihar and Baranya Counties can also be mentioned, however, the specialisation index of these counties is considerably lower than that of Komárom-Esztergom County. By the reference year (2013) Komárom-Esztergom County lost some of its strong specialisation, however it remained a dominant county in the field of hen breeding. The value and through that the 
Review on Agriculture and Rural Development 2014. vol. 3 (2) ISSN 2063-4803

rate of specialisation increased in Hajdú-Bihar County, while it fell back in Baranya County from the base year to the reference year.

The specialization increase in Budapest and in Szabolcs-Szatmár-Bereg County is also worth mentioning, which means that the spatial structure of hen farming is under constant change.

Table 4. Spatial specialisation of hen stock in Hungary

\begin{tabular}{|c|c|c|c|c|c|c|c|c|c|c|c|}
\hline Spatial Unit & 2003 & 2004 & 2005 & 2006 & 2007 & 2008 & 2009 & 2010 & 2011 & 2012 & 2013 \\
\hline Budapest & 0.62 & 0.67 & 0.63 & 1.13 & 1.23 & 1.30 & 0.86 & 1.18 & 1.41 & 0.84 & 2.16 \\
\hline Pest & 0.77 & 0.95 & 1.07 & 0.89 & 0.77 & 1.06 & 0.78 & 0.67 & 0.82 & 0.87 & 1.03 \\
\hline Central Hungary & 0.74 & 0.90 & 0.97 & 0.95 & 0.87 & 1.11 & 0.79 & 0.77 & 0.94 & 0.87 & 1.26 \\
\hline Fejér & 0.89 & 0.83 & 0.80 & 0.74 & 0.61 & 0.53 & 0.83 & 0.77 & 0.67 & 0.67 & 0.69 \\
\hline Komárom-Esztergom & 4.96 & 5.00 & 5.58 & 5.38 & 4.54 & 4.01 & 5.06 & 6.25 & 6.55 & 3.32 & 3.47 \\
\hline Veszprém & 0.71 & 0.70 & 0.59 & 0.61 & 0.68 & 0.85 & 0.72 & 0.68 & 0.58 & 0.71 & 0.76 \\
\hline $\begin{array}{l}\text { Central } \\
\text { Transdanubia }\end{array}$ & 1.67 & 1.66 & 1.69 & 1.63 & 1.43 & 1.36 & 1.65 & 1.88 & 1.85 & 1.23 & 1.29 \\
\hline Győr-Moson-Sopron & 0.83 & 0.99 & 0.71 & 0.91 & 0.96 & 0.69 & 0.85 & 0.83 & 0.84 & 0.92 & 0.96 \\
\hline Vas & 1.10 & 0.87 & 0.79 & 0.81 & 0.60 & 0.95 & 1.18 & 0.93 & 0.87 & 0.87 & 0.94 \\
\hline Zala & 0.85 & 0.93 & 1.10 & 1.07 & 0.91 & 1.37 & 1.18 & 0.76 & 0.87 & 1.25 & 1.21 \\
\hline West Transdanubia & 0.91 & 0.93 & 0.86 & 0.93 & 0.84 & 0.99 & 1.05 & 0.84 & 0.86 & 1.01 & 1.04 \\
\hline Baranya & 1.52 & 1.37 & 1.45 & 1.26 & 1.37 & 1.35 & 1.17 & 1.32 & 1.18 & 1.10 & 1.03 \\
\hline Somogy & 0.45 & 0.37 & 0.42 & 0.47 & 0.46 & 0.34 & 0.30 & 0.33 & 0.23 & 0.25 & 0.29 \\
\hline Tolna & 0.55 & 0.52 & 0.66 & 0.57 & 0.56 & 0.56 & 0.45 & 0.47 & 0.46 & 0.42 & 0.45 \\
\hline South Transdanubia & 0.82 & 0.73 & 0.82 & 0.75 & 0.78 & 0.72 & 0.62 & 0.69 & 0.60 & 0.57 & 0.57 \\
\hline $\begin{array}{l}\text { Borsod-Abaúj- } \\
\text { Zemplén }\end{array}$ & 0.78 & 0.85 & 0.77 & 0.89 & 1.04 & 1.02 & 0.99 & 0.82 & 0.71 & 0.70 & 0.78 \\
\hline Heves & 0.37 & 0.32 & 0.29 & 0.38 & 0.27 & 0.29 & 0.28 & 0.38 & 0.28 & 0.28 & 0.41 \\
\hline Nógrád & 0.95 & 0.36 & 0.41 & 0.36 & 0.39 & 0.31 & 0.36 & 0.30 & 0.31 & 0.25 & 0.35 \\
\hline North Hungary & 0.70 & 0.61 & 0.56 & 0.64 & 0.69 & 0.67 & 0.66 & 0.59 & 0.51 & 0.49 & 0.59 \\
\hline Hajdú-Bihar & 1.70 & 1.51 & 1.74 & 1.75 & 2.09 & 1.75 & 1.72 & 2.07 & 1.66 & 2.29 & 1.94 \\
\hline Jász-Nagykun-Szolnok & 0.53 & 0.71 & 0.69 & 0.56 & 0.61 & 0.65 & 0.45 & 0.40 & 0.39 & 0.42 & 0.44 \\
\hline $\begin{array}{l}\text { Szabolcs-Szatmár- } \\
\text { Bereg }\end{array}$ & 0.89 & 0.98 & 1.20 & 1.32 & 1.57 & 1.29 & 1.62 & 1.69 & 2.04 & 1.95 & 1.87 \\
\hline North Great Plain & 1.03 & 1.06 & 1.21 & 1.21 & 1.42 & 1.23 & 1.27 & 1.39 & 1.38 & 1.56 & 1.43 \\
\hline Bács-Kiskun & 1.18 & 1.26 & 1.08 & 1.16 & 1.03 & 1.24 & 1.13 & 0.91 & 0.96 & 1.33 & 0.99 \\
\hline Békés & 0.72 & 0.81 & 0.82 & 0.68 & 0.62 & 0.77 & 0.62 & 0.51 & 0.61 & 0.58 & 0.70 \\
\hline Csongrád & 1.34 & 1.26 & 0.74 & 0.71 & 0.80 & 0.64 & 0.86 & 0.92 & 1.02 & 1.00 & 0.88 \\
\hline South Great Plain & 1.09 & 1.13 & 0.92 & 0.91 & 0.86 & 0.96 & 0.92 & 0.79 & 0.87 & 1.03 & 0.88 \\
\hline
\end{tabular}

Source: Author's calculations based on KSH data

\section{CONCLUSIONS}

When examining the spatial specialisation of Hungarian livestock we can conclude that the values of the specialisation index show a diverse picture. Concerning the animal species, both increase and decrease can be observed in spatial specialisation in all cases, however if we examine the tendencies, special specialisation has bigger changes in hen production, 
while there is no change in sheep production. With regard to regional aspects, the winners of specialisation in case of animal production are the plain territories situated east from the River Danube. This means that on these lowland areas it is the animal production sector with the highest value of specialization that gives the significant part of the livestock in the given area (eg. county, region). This animal production sector forms the "skeleton" of the livestock in the region, around which the production complex is formed, and which determines the direction of development and significantly affects the other animal production sectors. In addition, it has the potential to shape the region and using the available favourable natural-socio-economic conditions it provides maximum economic yield enforcement effort at minimal expense. Beside the livestock industry that represents specialization, the development of the service sector, as well as the sectors supplying local needs, so most of the sectors of local importance, also have a significant role.

In my opinion, the processes and trends in animal production over the past decade are well reflected in the final study. In several cases, the available data show that in recent years there was a decrease in the livestock, except for cattle, which can be explained in many cases with the high feed prices (especially in the situation created by the fall of 2007), and sometimes with the low purchase price, the more difficult sales opportunities explained by the continuous inflow of cheap, low-quality products imported from abroad. Thus, animal production in our country is currently unprofitable in many cases, an activity likely to be degraded. The negative trends were further deteriorated, hopefully only temporarily, by the very high feed prices of 2007.

In the field of animal production, sometimes after a major setback of the stock, it may have a more favourable position in the future only with appropriate caution, with a well thought out agricultural policy taking into account the conditions of the European Union, and with a professional quality control. Long and medium term, it is very important that livestock would have an increasing role in Hungarian agriculture, in rural development, thereby with a further multiplicative effect.

\section{REFERENCES}

BENKŐ-KISS Á., BODNÁR K., KIS K., HORVÁth J. (2010): Preliminary investigation on innovation activity of agricultural ventures in South Great Plain Region in Hungary. Agrárés Vidékfejlesztési Szemle 5(1) supplement: 220-225.

BODNÁR K., HORVÁTH J. (2005): Különböző állattenyésztési ágazatok tőkeszükséglete. (in. A mezőgazdaság tőkeszükséglete és hatékonysága szerk.: Jávor A.). DAC AVK, Debrecen pp. 97-103.

HoRVÁTH J. (2002): Specializált és diverzifikált ágazati struktúrák a tejtermelésben. In: Jávor, A., Bede, Cs. (szerk.): Innováció, a tudomány és a gyakorlat egysége az ezredforduló agráriumában. DE-MTK - SZIE-MKTK Debrecen pp. 197-202.

KomAREK L. (2003): Baromfiágazati diagnosztika. Magyar Mezőgazdaság 43: 18-19.

KOMAREK L. (2004): A tágabb értelemben vett húsipar árualapjának változása a DélAlföldön, különös tekintettel a rendszerváltozás utáni időszakra. pp. 181-186. In: Abonyiné Palotás J., Komarek L. (eds.): 40 éves a Szegedi Tudományegyetem Gazdaság- és Társadalomföldrajz Tanszék. Gold Press, Szeged. 224. p.

KOMAREK L. (2007): A Dél-Alföldi régió súlyának, szerepének alakulása a hazai agrártermelésben. Comitatus - Önkormányzati Szemle 17( 9): 52-64.

KOMAREK L. (2008a): Állatállományunk alakulása. Magyar Mezőgazdaság 63(14): 16-17. KOMAREK L. (2008b): A hazai állatállomány alakulásának főbb jellemzői. A Földrajz Tanítása 16(4): 13-19. 
KOMAREK L. (2008c): A Dél-Alföld agrárszerkezetének sajátosságai. Csongrád Megyei Agrár Információs, Szolgáltató és Oktatásszervező Kht, Szeged. 143. p.

KOMAREK L. (2011): A hazai húsipari árualap abszolút specializációjának és koncentrációjának időbeni és területi alakulása. Agrár- és Vidékfejlesztési Szemle 6(2): 239-245. 